\title{
Avidity of IgG antibodies against excreted/secreted antigens of Toxoplasma gondii: immunological marker for acute recent toxoplasmosis
}

\author{
Avidez de anticorpos IgG anti-antígeno de secreção e excreção \\ de Toxoplasma gondii: marcador imunológico \\ de toxoplasmose aguda recente
}

Patrícia Regina Barboza Araújo $^{1}$ and Antonio Walter Ferreira ${ }^{1}$

\begin{abstract}
Detection of anti-toxoplasma IgM antibodies has frequently been used as a serological marker for diagnosing recently acquired toxoplasmosis. However, the persistence of these antibodies in some patients has complicated the interpretation of serological results when toxoplasmosis is suspected. The purpose of the present study was to evaluate the avidity of $\operatorname{IgG}$ antibodies against excreted/secreted antigens of Toxoplasma gondii by means of immunoblot, to establish a profile for acute recent infection in a single serum sample and confirm the presence of residual IgM antibodies obtained in automated assays. When we evaluated the avidity of IgG antibodies against excreted/secreted antigens of Toxoplasma gondii by means of immunoblot, we observed phase-specific reactivity, i.e. cases of acute recent toxoplasmosis presented low avidity and cases of non-acute recent toxoplasmosis presented high avidity towards the $30 \mathrm{kDa}$ protein fraction, which probably corresponds to the SAG-1 surface antigen. Our results suggest that the avidity of IgG antibodies against excreted/secreted antigens of Toxoplasma gondii is an important immunological marker for distinguishing between recent infections and for determining the presence of residual IgM antibodies obtained from automated assays.
\end{abstract}

Key-words: Toxoplasmosis. Serology. Avidity. Excreted/secreted antigens.

\section{RESUMO}

A detecção de anticorpos IgM antitoxoplasma tem sido freqüentemente utilizada como marcador sorológico para o diagnóstico de toxoplasmose de aquisição recente. Entretanto, a persistência destes anticorpos em alguns pacientes tem complicado a interpretação dos resultados sorológicos quando a toxoplasmose é suspeitada. A proposta deste trabalho foi avaliar a avidez de anticorpos IgG contra antígenos de secreção e excreção de Toxoplasma gondii por immunoblot, para estabelecer um perfil de infecção recente aguda em uma única amostra de soro e confirmar a presença de anticorpos IgM residuais obtidos nos testes automatizados. Quando a avidez de anticorpos IgG contra antígenos de secreção e excreção Toxoplasma gondii, por immunoblot, foi avaliada, observou-se reatividade estágio específica, ou seja, casos de toxoplasmose aguda recente apresentaram baixa avidez e os casos de infecção recente não aguda apresentaram alta avidez para a fração protéica de $30 \mathrm{kDa}$, que corresponde provavelmente ao antígeno de superfície- SAG-1. Nossos resultados sugerem que a avidez dos anticorpos IgG contra antígenos de secreção e excreção Toxoplasma gondii é um importante marcador imunológico para distinguir doença recente de infecção e determinar a presença de anticorpos IgM residuais detectados nos testes automatizados.

Palavras-chaves: Toxoplasmose. Sorologia. Avidez. Antígenos de secreção-excreção.

Toxoplasmosis is caused by an intracellular parasite, Toxoplasma gondii, which presents global distribution and varying epidemiological characteristics among different populations. The course of infection by Toxoplasma gondii is generally benign, since the vast majority of infected patients remain asymptomatic or only present mild symptoms. However, the infection can cause significant morbidity and mortality in developing fetuses and in immunocompromised individuals ${ }^{4}$.

Toxoplasmosis is generally diagnosed by demonstrating specific antibodies to Toxoplasma antigens in serum samples from infected patients. Serological diagnoses of acute toxoplasmosis have traditionally been made by detecting IgM antibodies or

1. Institute of Tropical Medicine, Faculty of Medicine, University of São Paulo, São Paulo, SP.

Address to: Dr. Antonio Walter Ferreira. Institute of Tropical Medicine/FM/USP. Av. Dr. Enéas Carvalho de Aguiar 470, 05403-000 São Paulo, SP.

Tel: 5511 3091-7022

e-mail: clawsmbf@usp.br

Recebido para publicação em: 04/06/2007

Aceito em: 11/03/2008 
by demonstrating significant increases in specific $\operatorname{Ig} G$ antibody levels, or both. However, because of the prevalence of high IgG Toxoplasma antibody titers in normal subjects and IgM antibodies detected several months or even years after acute infection in some individuals, interpretation of serological tests may be troublesome when acute toxoplasmosis is suspected ${ }^{13}$. Since IgG avidity evaluations for Toxoplasma infection serodiagnosis were introduced, this method has proved to be a highly useful procedure, especially in combination with conventional serological assays ${ }^{1920}$. However, low-avidity results do not rule out the possibility of recently acquired infection, because low avidity may persist for as long as one year following the acute infection and low or borderline avidity can occur in significant numbers of patients without specific IgM antibodies ${ }^{2}$. Several reports have emphasized the value of detecting specific antibodies against excreted/secreted antigens (ESAs) of Toxoplasma gondii for diagnosing acute toxoplasmosis ${ }^{59} 12$. Toxoplasma gondii ESAs constitute $90 \%$ of the circulating antigens in infected humans and thus are one of the first targets of the host immune response $\mathrm{e}^{1319}$. In our laboratory, we have recently developed a technique to obtain ESAs by incubating tachyzoites in human fibroblast cultures for a short period of time. In the present study, we evaluated IgG avidity against Toxoplasma gondii ESAs by means of immunoblot, in order to establish a profile for acute recent infection in single serum samples and to determine the presence of residual IgM antibodies detected in automated assays.

\section{MATERIAL AND METHODS}

Serum samples. One hundred and eighty serum samples were obtained from individuals during routine screening for toxoplasmosis and were analyzed using commercially available kits (VIDAS and AxSYM) to detect IgM and IgG antibodies against Toxoplasma gondii and specific $\operatorname{IgG}$ antibody avidity. These human serum samples were characterized using the classical serological methods of indirect immunofluorescence (IIF) and indirect hemagglutination (IHA) and by means of an automated system (VIDAS) to define study groups as follows: group I: 36 serum samples from patients suspected of recently acquired (acute) Toxoplasma gondii infection; group II: 61 serum samples from patients suspected of recently acquired but non-acute Toxoplasma gondii infection; group III: 39 serum samples from patients with chronic toxoplasmosis; and group IV: 44 serum samples with negative serology, which were taken to be healthy controls. In addition, group V consisting of 20 patients characterized serologically and clinically with rubella, mononucleosis and cytomegalovirus was included in this study in order to test the specificity of the method. Details of the specific serological tests for characterizing study groups I, II, III, IV and $\mathrm{V}$ are described in Table 1. The institution's ethics committee approved the project.

Serological tests. The serum samples had been routinely tested using two automated assays: AxSYM IgG and IgM (Abbott Laboratories, USA) and VIDAS Toxo IgG, IgM and IgG avidity (BioMérieux, Brazil); and using two non-automated methods:
Table 1 - Details of the specific serological tests for characterizing study groups I, II, III, IV and V.

\begin{tabular}{lcl}
\hline Group & Number & Description \\
\hline Group I & 36 & Serum samples from these patients exhibited specific \\
(acute) & IgM antibodies (titer $\geq 64$ ), IgG antibodies (titer $\geq 256)$ \\
& using IIF and IHA, and low avidity of $T$. gondii-specific \\
& IgG. Serum samples were positive for $T$. gondii-specific \\
& IgG and IgM using VIDAS. Three serum samples exhibited \\
& an "acute" serological profile without clinical manifestation.
\end{tabular}

Group II 61 Samples had specific IgM antibodies (titer $\geq 64$ ), (recent non-acute) associated with positive results for IgG (titer of $\geq 64$ ) using IIF and IHA, and high avidity of T. gondii-specific IgG. Serum samples were positive for T. gondii-specific IgG and IgM using VIDAS.

Group III 39 Serum samples exhibited specific IgG antibodies (chronic) (titer $\geq 64$ ), negative results for $T$. gondi $i$-specific IgM-(titer <16) using IIF and high avidity of $T$. gondii specific IgG. Serum samples were positive for $\operatorname{IgG}$ and negative for IgM T. gondii-specific using VIDAS.

\begin{tabular}{lrl}
\hline $\begin{array}{l}\text { Group IV } \\
\text { (healthy controls) }\end{array}$ & 44 & $\begin{array}{l}\text { All serum samples in this group were negative for } \\
\text { Toxoplasma-specific IgM and IgG using IIF and IHA. }\end{array}$ \\
\hline Group V & 20 & $\begin{array}{l}\text { Seven serum samples from individuals infected with } \\
\text { (other diseases) }\end{array}$ \\
& $\begin{array}{l}\text { Epstein-Barr, six serum samples from patients infected } \\
\text { with rubella virus and seven serum samples from } \\
\text { individuals infected with cytomegalovirus were tested. }\end{array}$ \\
\hline
\end{tabular}

IIF: indirect immunofluorescence assay, IHA: indirect hemagglutination.

indirect immunofluorescence (IIF) (BioMérieux, Brazil) and indirect hemagglutination (IHA) (BioMérieux, Brazil). The avidity of Toxoplasmagondii-specific IgG antibodies was determined as previously described by Hedman et al ${ }^{9}$. All commercially available reagents were used in accordance with the manufacturer's instructions.

Excreted/secreted antigen. RH-strain tachyzoites of Toxoplasma gondii were obtained from the peritoneal cavities of Balb/c mice that had been infected two days earlier, and were inoculated into human fibroblast cell cultures, for $3 \mathrm{~h}$ at $37^{\circ} \mathrm{C}$. The culture supernatants were centrifuged at $1,000 \mathrm{~g}$ for 10 minutes and were filtered through membranes of pore size $0.22 \mu \mathrm{m}$ (Millipore Corporation, Bedford, MA, USA). The ESAs were stored at $-70^{\circ} \mathrm{C}$ with $100 \mathrm{U} / \mathrm{ml}$ aprotinin (Sigma Chemical Co, St. Louis, MO, USA). To determine the mean number of intracellular parasites in host cells after $3 \mathrm{~h}$ at $37^{\circ} \mathrm{C}$, fibroblast cell cultures were trypsinated and counted in a Neubauer chamber.

Kinetics of ESA production. After washing three times with $\mathrm{PBS}$ at $\mathrm{pH} 7.2$, the human fibroblast cultures were inoculated with $1 \times 10^{8}$ tachyzoites and incubated at $37^{\circ} \mathrm{C}$. Five-milliliter aliquots of culture were taken at various times from one to 24 hours post-infection. Supernatants obtained at various times from the cultures were evaluated regarding the numbers and viability of tachyzoites by means of trypan blue and the protein concentrations were determined using the Bio-RAD DC Protein Assay, France.

Immunoblotting of IgG antibodies against ESA antigens. The ESAs were subjected to electrophoresis on polyacrylamide gels using a discontinuous sodium dodecyl sulfate (SDS) buffer system as described by Laemmli ${ }^{15}$, with $18 \%$ running gel and 3\% stacking gel. The running buffer contained 25mM TRIS, 
$192 \mathrm{mM}$ glycine, and $0.1 \%$ SDS at $\mathrm{pH} 8.3$. Gels were run at 5-6 $\mathrm{V} / \mathrm{cm}$ until the bromophenol blue marker reached the bottom. Molecular weight markers (Full Range Rainbow ${ }^{\mathrm{TM}}$, Amersham Life Sciences, England) were used to plot the calibration curve. Proteins separated by gel electrophoresis were further transferred to a $0.45 \mu \mathrm{m}$ (pore size) nitrocellulose membrane overnight, using a semidry transfer system. After transfer, nitrocellulose strips were blocked with 5\% skimmed milk (Molico, Nestlé) in PBS plus $0.05 \% \mathrm{~T} 20$ for $2 \mathrm{~h}$ at room temperature, in order to saturate protein-binding sites. Strips were further incubated for $18 \mathrm{~h}$ at $4^{\circ} \mathrm{C}$ with serum samples, diluted 1:25 in $1 \%$ skimmed milk with PBS T20. After incubation, the strips were washed with PBS plus $0.05 \%$ Tween 20 three times for 5 min and incubated for $2 \mathrm{~h}$ at room temperature with a 1:500 dilution of conjugate anti-human IgG-peroxidase (Sigma Chemical Co, St Louis, MO, USA) in PBS T20. After six washings with PBS plus $0.05 \%$ Tween 20, the strips were treated with $3 \mathrm{mg}$ of 4-chloronaphthol (Sigma Chemical Co, St Louis, MO, USA) in 10ml of methanol and $4 \mu \mathrm{l}$ of hydrogen peroxide.

IgG-avidity of ESA antigen by means of immunoblotting. Strips were incubated with serum samples, in duplicate, diluted 1:25 into 1\% skimmed milk in PBS plus $0.05 \%$ Tween 20 overnight at $4^{\circ} \mathrm{C}$. One strip of the duplicate was washed with PBS plus $0.05 \% \mathrm{~T} 20$ three times for $5 \mathrm{~min}$. The second nitrocellulose strip was washed with $8 \mathrm{M}$ urea solutions in PBS, three times for $5 \mathrm{~min}$. Both strips were incubated with conjugate anti-human IgG-peroxidase (Sigma Chemical Co, St Louis, MO, USA) diluted at 1:500 in PBS plus 0.05\% Tween 20 for $2 \mathrm{~h}$ at room temperature. After a further washing step, repeated six times for $5 \mathrm{~min}$ in PBS, the strips were treated with 3mg of 4-chloronaphthol (Sigma Chemical Co, St Louis, MO, USA) in $10 \mathrm{ml}$ of methanol and $4 \mu \mathrm{l}$ of hydrogen peroxide.

Avidity of Toxoplasma gondii-specific IgG by means of ELISA. The avidity of Toxoplasma gondii $\operatorname{IgG}$ antibodies was determined as described by Hedman', with some modifications. Microtiter plates were previously coated with $10^{5}$ tachyzoites/well obtained from peritoneal exudates of Balb/c mice that had been infected two days earlier with the RH strain of Toxoplasma gondii. Serum samples were then added in duplicate, diluted 1:16 in PBS on separate plates. After incubation for $45 \mathrm{~min}$ at $37^{\circ} \mathrm{C}$, the plates were subjected to differential washing methods as follows: one plate was washed with $8 \mathrm{M}$ urea solution in PBS for $5 \mathrm{~min}$, while the other plate was washed only with PBS T20 for $5 \mathrm{~min}$. In addition, both plates were washed twice with PBS T 20 for 5 min. Conjugate anti-human IgG-peroxidase (Sigma Chemical Co, St Louis, MO, USA) diluted at 1:3,000 in PBS T20 and incubated for $45 \mathrm{~min}$ at room temperature was added. After three washes in PBS, the reaction was developed using a substrate solution consisting of orthophenylenediamine at $0.5 \mathrm{mg} / \mathrm{ml}$ in $0.1 \mathrm{M}$ citrate-phosphate buffer ( $\mathrm{pH} 5.0$ ) and $0.012 \%$ $\mathrm{H}_{2} \mathrm{O}_{2}$. After incubation for $15 \mathrm{~min}$ at room temperature, the reaction was stopped with $2 \mathrm{~N} \mathrm{H}_{2} \mathrm{SO}_{4}$. The absorbance was measured at $492 \mathrm{~nm}$ by using a plate reader system (Titertek Multiskan Plus, Geneva, Switzerland). The avidity index was calculated as the ratio between the absorbance obtained for the plate washed with PBS plus urea and the absorbance for the plate washed with PBS without urea and was expressed as a percentage.

\section{RESULTS}

Non-automated serological assays. Out of the 200 human serum samples, 133 samples were positive for IgG-IIF and IgGIHA, 97 samples were positive for IgM-IIF and IgM-IHA, both with antibody titers $\geq 16$. All other serum samples from patients with heterologous infections (rubella, cytomegalovirus and mononucleosis) had negative specific IgG and IgM antibodies.

Automated serological assays and IgG avidity by means of ELISA. Out of the 200 samples, 136 were positive for IgG-VIDAS and 144 samples were positive for IgG-AxSYM. Ninety-seven serum samples were positive for IgM-VIDAS and 104 serum samples were positive for IgM-AxSYM. All other serum samples from patients with heterologous infections had negative specific IgG and IgM antibodies. For IgG avidity from VIDAS, out of 136 human serum samples, 91 had presented high-avidity IgG, nine had borderline-avidity IgG and 36 had low-avidity IgG. Among the IgG avidity results from ELISA, out of 136 human serum samples, 90 samples had high-avidity IgG, eight had borderline-avidity IgG and 38 had low-avidity IgG.

Kinetics of ESA production. During the first 12 hours of infection, the number of extracellular tachyzoites declined, and no host cells could be detected. During the next 12 hours, there was an increase in parasite numbers, and dead host cells were observed. The tachyzoites forms remained intact before and after inoculation, as observed by phase contrast microscopy. The ESA concentration in supernatants harvest from cultures at each study time was estimated and detected as early as one hour after infection. Levels of ESA only rose significantly in cultures after three hours, reaching a maximum at the end of the study period.

Immunoblotting of IgG antibodies against ESA antigens. Out of the 200 serum samples, 136 were reactive and revealed the same reactivity against fractions of different molecular weights. The eight discordant serum samples with regard to specific IgG antibodies did not occur between VIDAS and AxSYM, and the serum samples from patients with heterologous infection did not present any reactivity to protein fractions of Toxoplasma gondii ESA.

Avidity of IgG antibodies against ESAs by means of immunoblotting. Out of 136 human serum samples, $103 \mathrm{had}$ high-avidity IgG and 33 samples had low avidity IgG against the $30 \mathrm{kDa}$ fraction protein. Serum samples from acute recently infected patients had low avidity and the samples from non-acute and chronic patients had high avidity against the $30 \mathrm{kDa}$ fraction protein.

\section{DISCUSSION}

Serological evaluation of the time when Toxoplasma infection was acquired is of fundamental importance for pregnant women, since infection during pregnancy requires intervention and treatment. During this phase, both clinical manifestations and congenital toxoplasmosis may occur ${ }^{3}$. Several methods have been used to measure specific IgM antibodies as markers for toxoplasmosis infection ${ }^{4}$. However, in clinical practice, it is not unusual to observe persistent IgM antibodies for prolonged periods after the acute phase of infection ${ }^{1462022}$. 
Table 2 shows that, in our study, residual IgM antibodies were detected by VIDAS and AxSYM, and this was confirmed by the negative results found for IIF, IHA, high avidity tests (VIDAS) and clinical follow-up information (data not shown). IgM-VIDAS assays showed better performance (residual $\operatorname{IgM} n=64$ ) than seen with AXSYM (residual IgM $n=71$ ). VIDAS showed high specificity and positive predictive values with regard to detecting specific IgM antibodies ${ }^{11} . \mathrm{IgG}$ avidity determination is an important serological marker that can be used to distinguish between acute and nonacute disease in single serum samples, through confirming the presence or absence of residual IgM antibodies ${ }^{4101317}$.

Table 2 - Performance of automated assays for detecting residual IgM antibodies in the samples studied.

\begin{tabular}{lccc}
\hline & \multicolumn{3}{c}{ IgM antibodies } \\
\cline { 2 - 4 } Automated assay & positive $\left(\mathrm{n}^{\mathrm{o}}\right)$ & true positive $\left(\mathrm{n}^{\mathrm{o}}\right)$ & residual $\left(\mathrm{n}^{\mathrm{o}}\right)$ \\
\hline VIDAS & 97 & 33 & 64 \\
AXSYM & 104 & 33 & 71
\end{tabular}

True positive: Serum sample exhibited specific IgM antibodies (titer $>64$ ) using IIF and IHA, low avidity of specific IgG antibodies and clinical compatibility with acute recent toxoplasmosis.

However, recent studies on the kinetics of IgG avidity in pregnant women have observed high avidity in pregnant women who had been infected for at least three to five months and low avidity one year after the acute phase ${ }^{18}$. In addition, significant numbers of patients present borderline avidity results ${ }^{22}$.

Based on clinical information (data not shown) and conventional serological assays, we analyzed ELISA avidity and VIDAS avidity to determine residual IgM antibodies. For this, 71 serum samples were used to determine residual IgM and were subjected to avidity assays. The VIDAS and ELISA avidity assays showed similar performance in the panel of 71 residual IgM samples: respectively 60/71 and 59/71 samples presenting with high avidity. Borderline avidity results were observed in nine samples with VIDAS and in eight samples with ELISA (Table 3).

Problems in measuring specific IgG antibodies have only rarely been observed in laboratory practice. In our study too, we only observed false positive results for specific IgG antibodies in eight out of 200 samples analyzed, as confirmed by negative results found with IgG-IIF and IgG-IHA. In this panel of eight false positive IgG samples, $3 / 8$ (37.5\%) yielded positive results with IgG-AxSYM and 5/8 (62.5\%) were borderline IgG according to both automated assays (VIDAS and AxSYM) (Table 4). False positive results in relation to specific $\operatorname{IgG}$ antibodies may lead to wrong interpretation and diagnosis of congenital toxoplasmosis ${ }^{6}$. Development of different serological techniques has increased the difficulty in defining diagnoses, even in the presence of several markers in single serum samples, due to persistency in distinguishing between acute recent phases and non-acute recent phases.

In the Toxoplasma serology laboratory of the Palo Alto Medical Foundation, which is a diagnostic reference center, positive IgM results in pregnant women are confirmed by combining measurements of IgG, IgA, IgE antibodies and IgG avidity in serum samples obtained at various times during pregnancy. In public
Table 3 - Comparison of residual IgM antibodies obtained from automated assays and IgG avidity tests for 71 serum samples.

\begin{tabular}{lrrrrrr}
\hline & \multicolumn{5}{c}{ IgM residual serum samples } \\
\cline { 2 - 7 } IgG avidity result & \multicolumn{1}{c}{$\mathrm{n}^{-0}$} & $\%$ & $\mathrm{n}^{0}$ & $\%$ & $\mathrm{n}^{0}$ & $\%$ \\
\hline \multirow{2}{*}{ Low } & 2 & 2.8 & 4 & 5.6 & 0 & \\
Borderline/indeterminate & 9 & 12.7 & 8 & 11.3 & 0 & \\
High & 60 & 84.5 & 59 & 83.1 & 71 & 100.0 \\
\hline
\end{tabular}

Table 4 - Discordant results obtained using IIF, IHA, VIDAS and AXSYM for measuring Toxoplasma-specific IgG antibodies.

\begin{tabular}{|c|c|c|c|c|c|}
\hline \multirow{3}{*}{ Sample } & \multicolumn{3}{|c|}{$\begin{array}{c}\text { Toxoplasma gondii- specific } \\
\text { IgG antibodies }\end{array}$} & & \multirow{3}{*}{$\begin{array}{l}\text { ESA-specific } \\
\text { IgG antibodies } \\
\text { Immunoblot }\end{array}$} \\
\hline & IIF & IHA & VIDAS & $\overline{\text { AXSYM }}$ & \\
\hline & Titer/cutoff & Titer/cutoff & UI/cutoff & UI/cutoff & \\
\hline 1 & $<1: 16(<1: 16)$ & $<1: 16(<1: 16)$ & $<4.0(<4.0)$ & $20(<3.0)$ & NR \\
\hline 2 & $<1: 16(<1: 16)$ & $<1: 16(<1: 16)$ & $<4.0(<4.0)$ & $20(<3.0)$ & NR \\
\hline 3 & $<1: 16(<1: 16)$ & $<1: 16(<1: 16)$ & $<4.0(<4.0)$ & $27(<3.0)$ & NR \\
\hline 4 & $<1: 16(<1: 16)$ & $<1: 16(<1: 16)$ & $6.0(<4.0)$ & $10(<3.0)$ & NR \\
\hline 5 & $<1: 16(<1: 16)$ & $<1: 16(<1: 16)$ & $7.0(<4.0)$ & $3(<3.0)$ & NR \\
\hline 6 & $<1: 16(<1: 16)$ & $<1: 16(<1: 16)$ & $4.0(<4.0)$ & $3.5(<3.0)$ & NR \\
\hline 7 & $<1: 16(<1: 16)$ & $<1: 16(<1: 16)$ & $4.0(<4.0)$ & $4.0(<3.0)$ & NR \\
\hline 8 & $<1: 16(<1: 16)$ & )$<1: 16(<1: 16)$ & $4.0(<4.0)$ & $3.0(<3.0)$ & NR \\
\hline
\end{tabular}

clinics and some laboratories in Brazil, residual IgM antibodies are determined in single serum samples in combination with specific IgG antibodies and rarely with IgG avidity, due to the cost of equipment and reagents for performing this additional test.

In this respect, the present study focused on the potential for diagnoses in single serum samples by using the avidity of IgG antibodies against tachyzoite ESAs. These constitute most of the circulating antigens in acutely infected humans, and thus are one of the first targets of the immune response ${ }^{512}$. Based on different studies, we have recently developed a technique for obtaining ESAs by incubating tachyzoites in human fibroblast cell cultures for a short period of time ${ }^{214}$. At the outset of our studies on Toxoplasma gondii ESA, our concern was to rule out the possibility that the antigens could have been obtained from lysis of parasites during the procedure to produce the antigen. The results relating to ESA kinetics have indicated that the antigen obtained has a secretory or excretory origin. The kinetics of secretion-excretion show that ESAs can be detected within the first hour and reach their maximum concentrations within three hours of inoculation. This was similar to what had previously been observed by Hughes ${ }^{13}$ when they detected ESAs in serum during the initial period of infection.

Protein fractions, including P30, were recognized by IgG antibodies with the same reactivity patterns in patients with acute and non-acute disease, in agreement with the findings of Acebes ${ }^{1}$ and Meek $^{18}$ (Figure 1). However, the samples that presented false positive results in relation to specific $\operatorname{Ig} G$ antibodies in automated assays, and also the healthy individuals and individuals with other diseases, did not present reactivity of $\operatorname{Ig} G$ antibodies against protein 


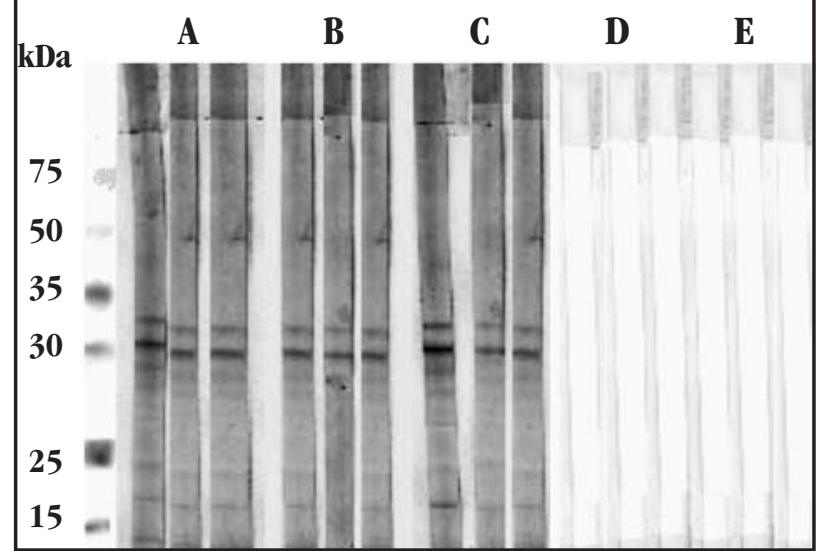

Figure 1 - Antigenic profile of excreted/secreted antigens of Toxoplasma gondii recognized by specific IgG antibodies in serum samples from acute recent cases (A), non-acute recent case (B), cases of chronic infection (group C), bealthy individuals (group D) and cases of other diseases (group E), as determined by immunoblot.

fractions of Toxoplasma gondii ESA, as seen using immunoblot (Figure 1). These results differed from those of $\mathrm{Hafid}^{8}$ and $\mathrm{Meek}^{18}$, which were based on ESA obtained from African green monkey kidney cell cultures and from infected mice.

The avidity performance of $\operatorname{IgG}$ against the protein fraction of ESA-P30 in the panel of 33 acute disease samples and 61 non-acute samples was reliable: 33/33 present low avidity and 61/61 present with high avidity, respectively. Three out of 36 serum samples with serological characteristics of acute diseases but without compatible clinical features present high avidity in assays of IgG avidity against ESA by means of immunoblot (Figure 1). In addition, no indeterminate results for assays of $\operatorname{IgG}$ avidity against ESA by means of immunoblot were observed in the present study (Figure 2).

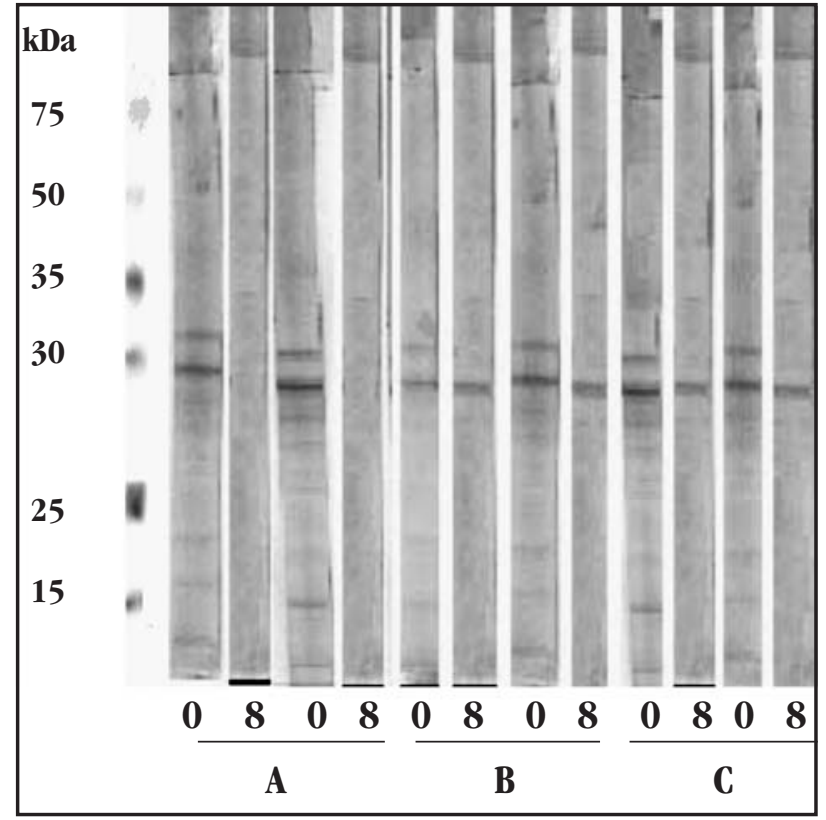

Figure 2 - Antigenic profile of excreted/secreted antigens of Toxoplasma gondii recognized by specific IgG antibodies in serum samples from acute recent cases (A), non-acute recent cases (B) and chronic infection cases (group C), as determined by immunoblot without or with $8 M$ urea treatment. $0=$ without urea; $8=8 M$ urea
Our data do not agree with those in the study by Marcolino ${ }^{15}$, which could not distinguish between patients with acute and nonacute disease through analyzing IgG avidity against P30 obtained from the peritoneum of infected mice. Most commercial kits and in-house methods use tachyzoites grown in mouse or other cell cultures and this factor is probably associated with the intrinsic proprieties of the technique used. This would explain the better performance of assays of IgG avidity against ESA protein fractions obtained from human fibroblast culture in distinguishing between acute and non-acute disease. Our date suggest that IgG avidity against P30 (probably SAG-1) can be considered to be an immunological marker for distinguishing acute disease from non-acute disease, thereby confirming the presence of residual IgM antibodies obtained for automated assays in single serum samples.

\section{REFERENCES}

1. Acebes MV, Diez B, Garcia-Rodrigues JA, Viens P, Cisterna R. Detection of circulating antigens in the diagnosis of acute toxoplasmosis. The American Journal of Tropical Medicine and Hygiene 51: 506-511, 1994.

2. Bessières MH, Le Breton S, Séguéla JP. Analysis by immunoblotting of Toxoplasma gondii exo-antigens and comparison with somatic antigens. Parasitology Research 78: 222-228, 1992.

3. Camargo ME. Toxoplasmose. In: Ferreira AW, Ávila SL (eds) Diagnóstico Laboratorial das Principais Doenças Infecciosas e Auto-Imunes. Editora Guanabara-Koogan, Rio de Janeiro, RJ,p. 278-288, 2001.

4. Camargo ME, Silva SM, Leser PG, Granato CH. Avidez de anticorpos IgG específicos com marcadores de infecção primária recente pelo Toxoplasma gondii. Revista do Instituto de Medicina Tropical de São Paulo 33: 213-218, 1991.

5. Cesbron-Delauw MF, Capron A. Excreted/secreted antigens of Toxoplasma gondii - their origen and role in the host-parasite interaction. Research Immunology 144: 41-42, 1993.

6. Ferreira AW, Camargo ME. Toxoplasmosis and the laboratory: Diagnosis and a constant striving for improvement. Revista Instituto Medicina Tropical de Sao Paulo 44: 119-120, 2002.

7. Fischer HG, Stachelhaus S, Sahm M, Meyer HE, Reichmann G. GRA7, an excretory $29 \mathrm{kDA}$ Toxoplasma gondii dense granule antigen released by infected host cells. Molecular and Biochemical Parasitology 91: 251-262, 1998.

8. Hafid J, Tran MSR, Raberin H, Akono ZY, Pozzetto B, Jana M. Detection of circulating antigens of Toxoplasma gondii in human infection. The American Journal of Tropical Medicine and Hygiene 52: 336-339, 1995.

9. Hedman K, Lappalainen M, Seppaia I, Makela 0. Recent primary toxoplasma infection indicated by a low avidity of specific IgG. Journal Infection Diseases 159: 736-740, 1989.

10. Hofgarter WT, Swanzy S, Bacina RM, Condon J, Gupta M, Maltlock PE, David L, Bergeron L, Plorde JJ, Fritsche TR. Detection of immunoglobulin G (IgG) and IgM antibodies to Toxoplasma gondii: Evalution of four commercial immunoassay system. Journal of Clinical Microbiology 35: 3313-3315, 1997.

11. Holliman RE, Raymond R, Renton N, Johnson JD. The diagnostic of toxoplasmosis using $\operatorname{IgG}$ avidity. Epidemiology Infection 112: 399-408, 1994.

12. Hughes HP, Hudson L, Fleck DG. In vitro culture of toxoplasma gondii in primary and established cell lines. International Journal Parasitology 16: 317-322, 1986.

13. Hughes HPA, Van Knapen F. Characterization of a secretory antigens from Toxoplasma gondii and its role in circulating antigen production. International Journal for Parasitology 12: 433-437, 1981.

14. Johnson LL, Berggren KN, Szaba FM, Chen W, Smiley ST. Fibrin-mediated protection against infection-stimulated immunopathology. Journal Experimental Medicine 197: 801-816, 2003.

15. Laemmli UK. Cleavage of structural proteins during the assembly of the head of bacteriophage T4. Nature 227: 680-685, 1970. 
16. Liesenfeld 0, Montoya JG, Kinney S, Press C, Remington JS. Effect of testing IgG avidity in the diagnosis of toxoplasma gondii infection in pregnant women. Journal Infection Diseases 183: 1248-1253, 2001.

17. Marcolino PT, Silva DA, Leser PG, Camargo ME, Mineo JR. Molecular markers in acute and chronic phases of human toxoplasmosis: determination of immunoglobulin $\mathrm{G}$ avidity by Western blotting. Clinical Diagnostic Laboratory Immunology 7: 384-389, 2000.

18. Meek B, Diepersloot RJ, Van Gool T, Speijer D, Peek R. IgM recognition of recombinant Toxoplasma gondii antigens by sera of acutely or latently infected humans. Diagnostic Microbiology Infection Diseases 45: 45-52, 2003.

19. Montoya JG. Laboratory diagnosis of Toxoplasma gondii infection and toxoplasmosis. Journal Infection Diseases 185 (supl 1): S73-82, 2002
20. Montoya JG, Huffman HB, Remington JG. Evaluation of the immunoglobulin $\mathrm{G}$ avidity test for diagnosis of toxoplasmic lymphadenopathy. Journal Clinical Microbiology 42: 46274631, 2004.

21. Montoya JG, Liesenfeld 0. Toxoplasmosis. Lancet 12 363(9425):1965-1976, 2004 .

22. Prigione I, Facchetti P, Lecordier L, Deslee D, Chiesa S, Cesbron-Delauw MF Pistoia V. T cell clones raised from chronically infected healthy humans by stimulation with Toxoplasma gondii excretory-secretory antigens crossreact with live tachyzoites: characterization of the fine antigenic specificity of the clones and implications for vaccine development. Journal Immunology 164: 3741-3748, 2000. 